\title{
日本原子力学会譩
}

Vol. 44, No. 3

2002 年 3 月

\section{目次 次}

巻 頭 言 市場活力という妄言

会告「和文論文誌」の創刊と今後の「日本原子力学会誌」の新しい飛躍にあたり .西 部 邁 $223(1)$

.住田健二 $\mathbf{2 2 4}(2)$

N E W S 原子力界における最近の動き·海外情報

$226(4)$

特 集 プルサーマルーその意義と安全性 藤家 洋一, 竹田 敏一, 佐治 悦郎,

石島 清見, 市川 迬生, 古屋 廣高, 住田 健二 238 ( 16 )

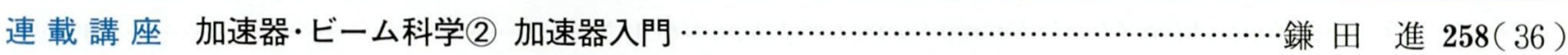

原子力施設訪問 核燃料サイクル開発機構東濃地科学センター訪問記

平 野雅美 $272(50)$

会 議 報 告 アジアにおける原子力利用の新しい展開と地域協力の役割

一第 2 回アジア原子力協カフォーラム (FNCA) 大臣級会合によせて………町末 男 275( 53 )

ACTINIDES-2001国際会議 …………………............................... 川 徹 278( 56 )

平成13年度日本原子力研究所成果報告会「革新的技術と安全性研究」

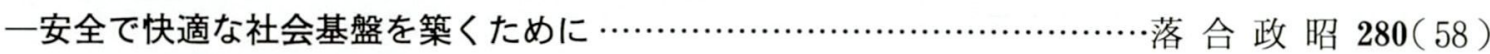

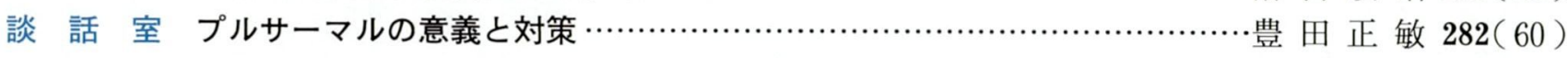

BWR 3 次元プラントシミュレータの国際ベンチマーク ………………堀田亮年 284(62)

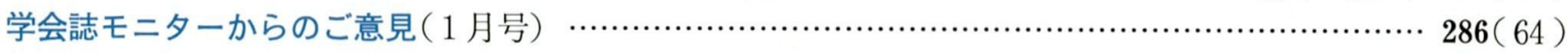

新刊紹 介

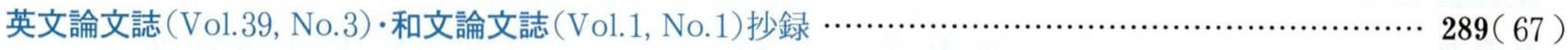

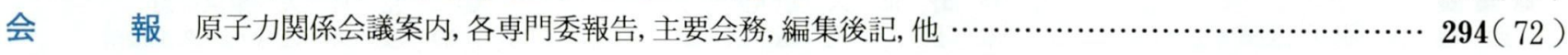

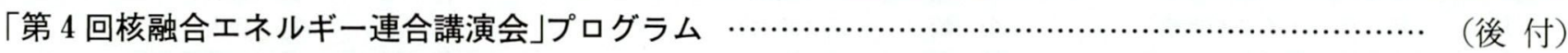

「第34回日本原子力学会賞」受賞概要 …………........................................................ (後 付)

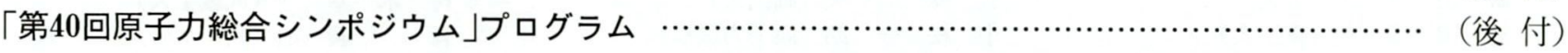

\section{表紙写真}

BWRにおける制御棒引き抜きを想定した場合の周辺燃料における燃料棒出力分布の遷移。米国ピーチ ボトム 2 号炉のタービントリップ試験点TT 2 を想定し, 樑く挿入された制御棒 1 本を引き抜いた場合の出 力過渡事象を 3 次元プラントシミュレータ TRAC/BF 1-ENTREEにより解析。炉心全体の拡散計算によ り得られる中性子束, 中性子流境界条件に, 格子計算により得られる燃料バンドル内詳細出力分布形状を組 み合わせることにより, 非均質性の顕著な BWR 燃料バンドルについて燃料ピン出力を再構築するアルゴ リズムが適用されている。これをサブチャンネル解析コードと組み合わせた過渡時詳細サブチャンネル解 析の研究成果は, 本会「2002年秋の大会」にて発表予定。詳細および BWR タービントリップ国際ベンチ マークの概要については本号「談話室」参照。（写真提供：(梾テプコシステムズ）

【複写をされる方に】本誌に掲載された著作物を複写する場合は, 著作権者から複写権の委託を受けている学術著作権協会( ( $107-0052$ 東京都港区赤坂 9-6-41 乃木坂ビル 3F. TEL 03-3475-5618, FAX 03-3475-5619) から許諾を受けて下さい。ただし，アメリカ合衆国における 複写については, Copyright Clearance Center, Inc.(222Rosewood Drive, Danvers, MA 01923, USA. TEL(508)750-8400, FAX(508)7504747 ; www.copyright.com)へ。 